lower the interfacial tension at the wool-air surface, with resultant increase of the spreading coefficients of urea. formaldehyde, polyamide and acrylio polymers on the fibre. This leads to more uniform coverage of the surface scales, and hence improved shrink resistance. This approach might allow selection of a particular resin, coupled with a suitable pretreatment, so as to ensure good spreading, and therefore high shrink resistance.

Fornial contributions were made by Prof. M. Chaikin, Mr. G. F. Flanagan, Dr. G. Laxer and Dr. V. A. Williams during the vigorous discussions which followed the main papers.
In summing up, Dr. E. G. Carter, of the International Wool Secretariat, congratulated the speakers on their attempts to provide sound theoretical bases for setting and shrinkproofing processes. He stressed the need for developing more analytical methods, suoh as those described for thiol, disulphide and lanthionine, whioh might help in discriminating between alternative theories. The measure of agreement between various speakers was indicative of closer collaboration between physicists and chemists than was apparent during his first visit to Australia in 1955 .
S. J. LEACB Brian Mulligan

\title{
MINING AND ENGINEERING GEOPHYSICS IN SCANDINAVIA
}

$\mathrm{T}$ HE fourth Nordic Meeting for Mining and Engineering Geophysies was held in Trondheim, Norway, during January 6-8, 1964.

The meeting on January 6 was a joint meeting with the sixth Nordic Geological Winter Meeting. More than 200 geologists, geophysicists, and technicians attended this, while the attendance amounted to about 110 for the remaining days. The participants included about 45 Norwegians, 40 Swedes, 20 Finns, 4 Danes and 1 Icelander. The sessions were presided over by Dr. David Malmqvist, Boliden Mining Co., Sweden, chairman of the planning committee, while the practical arrangements were organized by Andreas Eriksen, mining engineer, Sydvaranger Mining Co., Oslo, chairman of the organizing committee.

The joint meeting opened with an address of welcome by Prof. A. Hofseth, Norwegian Technical Highschool, Trondheim, in which he emphasized the importance of co-operation between mining engineers, geologists and geophysicists. The technical programme began with geological papers and shifted gradually towards more geophysical fields.

C. O. Mathiesen (Norway) gave an account of the copperfield at Bidjovagge, Finmark (northern Norway). The geophysical investigation of this field was given four years ago by G. F. Sakshaug at the second Nordic Meeting for Mining Geophysies. Mathiesen presented a geological picture according to which the ore-body follows a folded anticline running north-south. The deposit is estimated to be $2 \cdot 2$ million tons and the richest part of the deposit contains $2 \cdot 3$ per cent copper and 0.032 ounce gold. Another geological paper dealing with a new promising nickel deposit in Nord-Hitura (eastern Finland) was presented by V. Yletynen (Finland). The ore consists of pentlandite, pyrrhotite and chalcopyrite. A geological survey of the iron-titanium deposit at Rausand (western Norway) was presented by H. P. Geis (Norway). The ore-body is always associated with lenses of amphibolite and has been followed for a distance of about $55 \mathrm{~km}$. Folding of the ore-body and the host rock has occurred in connexion with the Caledonian orogenesis. The ore consists of magnetite and ilmenite, the latter containing much hæmatite.

Scott Smithson (Norway) reported twice; first, he gave a paper dealing with geological and geophysical investiga. tions of Norwegian Precambrian granites. From gravimetric measurements the thicknesses of several granite masses have been computed. The range of $1-4 \mathrm{~km}$ for the thicknesses of Precambrian granites is very small compared with younger granites. In his second paper, Scott Smithson gave some preliminary results of gravity meas. urements over the Jotun nappes of the Caledonides. The measurements have been facilitated by helicopter trans. portation in order to locate stations where terrain effects are at a minimum. The Bouguer anomalies range from -70 to -80 mgals both north and south of the nappes and rise to a maximum of about $-30 \mathrm{mgals}$ in the centre of the nappes. The calculated total thickness of the nappes ranges from about 5 to $10 \mathrm{~km}$ depending on the density contrast. The latter value corresponds to a provisional density contrast of $0.12 \mathrm{~g} /$ c.c.

P. F. Trøften (Norway) described an investigation of recordings of ore finds in northern Norway. From 1895 up to recent times 1,680 localities have been reported. Trøften concluded that apparently all outcropping orebodies and boulders have been located by 'old-timo' prospectors. "The Aims and Means of Ore-prospecting", was the title of a paper given by G. Törnquist (Sweden). Once again emphasis was placed on the co-operation between geologists, geophysicists and mining engineers, especially with regard to interpretation and re-interpretation. An estimate of the probability for new ore-bodies and for gains was given.

Applications of geophysics to geological mapping were demonstrated in three papers. V. Marmo (Finland) outlined the procedure used by the Finnish Geological Survey, where aeromagnetic maps are used by field geologists, and he presented several examples. Giving examples from the iron provinces at Sør-Varanger in northern Norway and at Arendal in southern Norway, as well as from the anorthosite field at Egernsund (south-western Norway), Prof. J. Bugge (Norway) gave an account of the usefulness of aeromagnetic surveys. Finally, J. Eklund (Sweden) described air-borne radiometric surveying of potassium, thorium and uranium in application to geological mapping.

A series of more general topics was opened by $G$. Jelstrup (Norway), who gave a review of the gravimetric surveying of Norway; he was followed by R. Kjær (Norway), who dealt with geomagnetic mapping. Two papers concerned with seismology were presented by research workers from Bergen University (Norway). A. Kvale gave an account of the seismic measuroments across the Skagerrak indicating $\mathbf{4 0 0}$ metres of Quaternary sediments and 2,960 metres of triassic sediments and/or phyllite deposited on granite and gneiss. The depth of the Mohorovičić discontinuity is computed to be $30 \mathrm{~km}$. Aeromagnetic traverses along the Norwegian coast showed several positive anomalies. M. Sellevold reported a series of refraction seismic traverses in northern Norway. A thin layer with a velocity of $7 \cdot 4-7 \cdot 5 \mathrm{~km} / \mathrm{sec}$ was traced between the basaltic layer of about $6.5 \mathrm{~km} / \mathrm{sec}$ and the mantle of about $8.3 \mathrm{~km} / \mathrm{sec}$ on the $300-\mathrm{km}$ long traverse from Troms $\varnothing$ to Muinio as well as on the traverse from Vardø to Kirkenes. An analysis of the $P$-waves of the earthquake on December 15, 1962, near Bodø, revealed likewise a thin-layer velocity of $7 \cdot 47 \mathrm{~km} / \mathrm{sec}$. R. Ronstad (Norway) described an attempt to establish a Fennoscandian gravimetric map. Ore-deposits were plotted, geological structures indicated, and also determinations of the geological age given. This section of the meeting was rounded off by $\mathrm{H}$. Major (Norway), who presented preliminary results of the geothermal gradient for a selection of mines. In general the gradient amounted to $1^{\circ} \mathrm{C}$ per 50 metres. 
The remaining fifteen papers covered various branches of applied geophysics, such as electrical, magnetic, geochemical and seismic investigations, case-histories, use of computing machines, etc. S. Werner (Sweden) presented the case-history of the Stora Sahavaara iron ore-body (Northern Sweden). The ore-body was recognized in 1918 by means of the Tiberg magnetometer; however, no development or mining was undertaken. Modern measurements commenced in 1960 utilizing gravimeters and ground as well as air-borne magnetometers. Extensive drillings have given rise to control of the computed tonnage, the size, the dimensions and the iron content of the ore-body. Examples of geochemical exploration were given by B. Bølviken (Norway): as a whole, the samples were taken in streams and brooks. A statistical investigation of aeromagnetic anomalies was demonstrated by $\mathbf{M}$. Puranen (Finland), while J. D. Cornwell (Sweden) gave an interpretation of some aeromagnetic anomalies from northern Sweden. Variations of sheet- and fault-type anomalies were described in connexion with the Tjaurekah fold and the fault complex associated with the Tärendo gabbro. A magnetic anomaly of $4,000 \gamma$ was considered to be due to an unusual contact between the gabbro and granite. Two papers dealt with the seismic method of surveying. S. Johansson (Finland) gave an address on the application of the hammer seismograph model, FS-2, for engineering projects such as constructions of roads, dams, canals, bridges, etc. Several results wero given. In the second paper, B. Hasselström (Sweden) presented a series of refraction seismic determinations in relation to the determination of overburden and to the localization of weathered rocks. Examples included the application of the method in drawing up plans for power stations, harbours, tunnels, etc.

A. Metzger (Finland) described a method for electrical coring and its application for soil determinations. A. Breen (Norway) discussed measurements of the quotient of electromagnetic field strength by means of symmetrically built measuring apparatus. The design of a portable electromagnetic instrument ('Slingram') was shown by $K$. Westerberg (Sweden). A similar system has been used for several years with promising results for prospecting by aeroplane and helicopter. The numerical calculation for this now instrument was givon by D. Malmqvist (Sweden), who presented a serios of graphs and tables. L. Granar (Sweden) gave an account of an improvement of the 'compensator' method developed by $K$. Sundberg some forty years ago, while $H$. Brækken (Ncrway) discussed the inducto-electric method and demonstrated some experimental evidence. The series on electrical methods was concluded by D. S. Parasnis (Sweden), who gave a review of the resistivity method and presented several examples of the application and the utility of this method over the past forty years.

H. P. Moxes (Norway) presented an approach to the calculation of aeromagnetic and groundmagnetic measurements by means of the electronic computer GIER. The effect in different elevations as well as the derivative components of the anomalies were considered. A. Vogel (Sweden) spoke on the interpretation of magnetic and gravimetric anomalies by means of the least-squares method and by the utilization of electronic computers. The data originated from a deep-seated oruptive massive.

At the business meeting reports were given by the various committees. The planning committee introduced rules and statutes for a Nordic Association for Applied Goophysics, one of the aims being to promote and enlarge Nordic co-operation within the domain of applied geophysics and its adjacent fields: the business meeting accepted the proposal unanimously. The following officers were elected: President, S. Werner (Swoden); Secretary/treasurer, J. Espersen (Sweden); Council Members, H. Brækken (Norway), M. Puranen (Finland) and S. Saxov (Denmark); Representatives, G. Törnqvist (Sweden), A. Breen (Norway), A. Metzger (Finland) and M. Mrag (Denmark).

It was decided that the committees for geophysical education, for technical mapping problems and for a Scandinavian gravity map should continue for one more period. Committees for scale-model experiments, and for the applicability and the suitability of electronic computers in applied geophysies, were constituted. An invitation was accepted for the fifth Nordic meeting for applied geophysies to be held in Sweden in approximately two years' time.

Following the meeting, the participants were invited to a luncheon-visit at the Norwegian Geological Survey. The managing director, $K$. Ingvaldsen, gave a review of the institution. The Norwegian Geological Survey was originally a geological survey with headquarters in Oslo; however, a few years ago the survey moved to new buildings in Trondheim; at the same time the geophysical survey and the geochemical laboratory were incorporated. At present, the Survey employs about 150 peoplo. The visiting delegates had an opportunity of seeing the various divisions and of gaining a definite impression of the many activities of the Survey.

On January 9 an excursion was organized to Fosdalen Mine, some $150 \mathrm{~km}$ north of Trondheim, and about 50 members of the meeting participated. Chief-engineer C. W. Carstens welcomed the guests, and Ø. Logn, geophysical engineer, gave a detailed lecture with a series of slides, figures and graphs of the geophysical background of the Mine. He also gave details concerning the drillings and arranged for an exhibition of various instruments and apparatus. Afterwards, a dinner was held with the personnel at the Mine acting as hosts.

It can thus be concluded that the fourth Nordic Meeting for Mining and Engineering Geophysies was most successful, the attendance being 100 per cent higher than at the second meeting in December 1959 and 50 per cent higher than at the third meeting in November 1961. The establishment of the Association as well as the creation of the journal, Geoexploration-the first two issues being published in 1963 and three issues being planned for 1964-. are impcrtant contributions to co-operation in the fields of mining and engineering geophysics. Svend Saxov

\section{EXPERIMENTAL PSYCHOLOGY}

\begin{abstract}
A $S$ the opening number of the twentieth volume of the Aritish Medical Bulletin, an 80-page issue has been published concentrating on experimental psychology*. This is introduced and edited by Prof. Summerfield and contains fifteen short, but informative, articles ranging from human learning, short-term memory, selective attention, and vigilance, to experimental investigations of sleep, ageing and drugs. Some subjects are omitted

* British Medical Bulletin. Experimental Psycholoon, 20, No. 1; January 1964. (London: The British Council.) 308 .
\end{abstract}

which might have beon of particular interest to medical readers; as Prof. Summerfield points out: "Little is said about work on emotion, personality and social behaviour, or on problems derived from psychiatry". In spite of these omissions, this is a very well-organized, very competent review of those areas dealt with. All are written by experts, many of whom describe work of their own, not always published, thus giving a sense of urgeney and of being up to date to their contributions. The bibliographies are uniformly excellent and will take the 